\title{
Climate Change in Sub-Saharan Africa: A menace to Agricultural productivity and Ecological protection
}

\author{
${ }^{* 1}$ IBE, GO; ${ }^{2}$ AMIKUZUNO, J \\ ${ }^{l}$ Department of Forestry and Environmental Management, College of Natural Resources and Environmental Management, Michael Okpara \\ University of Agriculture, PMB 7267, Umuahia, Umudike, Abia State, Nigeria \\ ${ }^{2}$ Department of Climate Change and Food security, Faculty of Agricultural Business and Communications, University for Development \\ Studies, Nyankpala Campus Tamale, Ghana \\ *Corresponding author Email: ibe.geraldine@ mouau.edu.ng
}

\begin{abstract}
Due to inadequate adaptation capacity, Sub-Saharan Africa has been depicted as the most vulnerable region with regards to global climate change, this is because of its reliance on agricultural activities for sustenance to livelihood which is highly sensitive to climate variables such as temperature variation, rainfall intensity, humidity patterns, and other extreme weather events. This paper reviews how climate change constitutes a menace to agricultural productivity and ecological protection using a qualitative approach. And importantly suggests ways to overcome such problems. Relevant literature was gathered from secondary data through articles, reports, journals from scientific publications, online websites and Conference Papers. From the review, it is revealed that climate change in Africa has a very significant effect on average temperature, rainfall patterns, and extreme weather events. It was also reviewed that climate has a negative effect on agricultural production and the ecological niche in Sub-Saharan Africa. Evidently, due to past and present climate change; agricultural land, growing season and yield as well as, ecological degradation will cause a decline to sustainable development in Sub-Saharan Africa, which is the center of this problem. Climate change adversely affects biodiversity protection through aggravated weather conditions, increased temperature, increased land salinity, excessive rainfall, storms, hurricanes and tornadoes which climax in ecosystem ruin. This review has clearly confirmed that Sub-Saharan Africa is indeed the most vulnerable region to climate change. To this end, policies aimed at promoting farm level adaptation strategies and mitigation of climate change with regards to ecological protection are highly recommended.
\end{abstract}

\section{DOI: https://dx.doi.org/10.4314/jasem.v23i2.20}

Copyright: Copyright ( 2019 Ibe and Amikuzuno. This is an open access article distributed under the Creative Commons Attribution License (CCL), which permits unrestricted use, distribution, and reproduction in any medium, provided the original work is properly cited.

Dates: Received: 16 December 2018; Revised: 20 January 2019; Accepted 29 January 2019

Keywords: Climate change, Ecological protection, Sub-Saharan Africa, Sustainable development.

Climate change is the variation in the statistical distribution of average weather conditions over a prolonged period of time in any region of the world (Adetayo and Owolade, 2012; Ikehi, 2014; Ikehi et al., 2014a). It reflects abnormal variations to the expected climate within the earth's atmosphere and subsequent effects on other parts of the earth which has extensive impacts on the already daunting challenges facing sustainable development, especially in Sub-Saharan Africa. Thus, an urgent response to support climate change mitigation and adaptation in Africa, cannot be underestimated. Even though the continent is the least contributor to greenhouse gases, still, it is the most vulnerable to the adverse impacts of global climatic change, due to inadequate adaptive capacity ICSSDA (2017). In the Sub-Saharan Africa, because Agriculture is one of the sectors, which is sensitive to global warming, most farmers make low crop yields due to the incidents of extreme weather conditions such as high and fluctuating rainfall patterns, flooding, droughts, high temperature, and other disparaging weather conditions caused by climate change. All climate change patterns are a major concern in many areas of socio-economic activities, especially agriculture and forestry. This is a major threat for biodiversity and ecosystem function (Lepetz et al., 2009).

The objective of this study therefore, is to discuss how climate change has become a serious menace to agricultural productivity and ecological protection and suggests ways to overcome these problems. This review in the end will seek to create an enabling document for knowledge sharing which would lead to informed decision making in climate sensitive areas such as natural resources, agriculture and the ecosystem in general.

\section{MATERIALS AND METHODS}

Study Area: The study area is the Sub-Saharan Africa (Figure 1). The methodological approach consists of the study area and data collection strategy. The second largest continent in the world is Africa and it is 
bounded on the west by the Atlantic Ocean, and on the north by the Mediterranean Sea, and on the east by the Red Sea and on the south by the Indian Oceans (Mabogunje et al., 2017; National Geographic Society, 2012). According to (Mabogunje et al., 2017; National Geographic Society, 2012), the total landmass of Africa is around 11,724.000 square miles $(30,365.000$ square $\mathrm{km})$, and the continent measures approximately 5000 miles $(8000 \mathrm{~km})$ from the north to south and around 4600 miles $(7400 \mathrm{~km})$ from the east to west. United Nations, 2016 stated that, its population has been increasing from the estimated 478 million in the 1980 s to the recent estimate of nearly 1.2 billion and this is predicted to rise to 1.5 billion by 2025 and 2.4 billion by 2050. Sub-Saharan Africa lies almost exclusively within tropical latitudes. According to UNEP (2002) two-thirds of its land surface can be classified as fragile desert or dry land, away from the equator, average annual rainfall declines rapidly and this is characterized by higher variability.

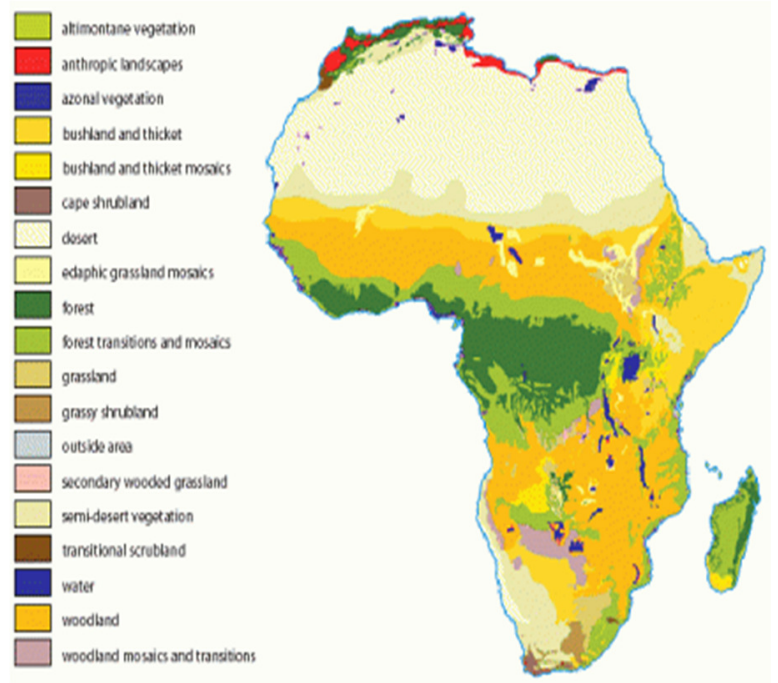

Fig 1: Map of Africa and the Sub-Saharan zones Source: Frimpong, 2014.

https://i1.wp.com/www.herald.ng/wpcontent/uploads/2014/03/afric aland.gif

Data Collection: Relevant literature was gathered from secondary data through articles, publications, IPCC Reports, UN Reports, journals from scientific publications, online websites and conference papers and libraries. This search was conducted in libraries and on Google search engine with "Climate Change in Sub-Saharan Africa" as the title for obtainable literature. Furthermore, the search for literature on climate change impact was conducted in Sub-Saharan African countries that are predominantly affected by climate change. These sources encompassed studies from the WESS Reports, UN Reports, IPCC Reports, online websites and conference papers. Furthermore, data were also collected from cited literature for the sample studies of this paper. The study is qualitative in nature, however, further integration of quantitative and qualitative evidence to assess climate change impact in Africa is still very much recommended.

\section{RESULTS AND DISCUSSIONS}

Causes of Climate Change: The main causes of climate changes include: increased temperature and extremes on both land and water; change in rainfall pattern which is the variability in its onset, seasonal distribution and extremes; increased frequency and intensity of large storms and tropical cyclones, increased evaporation losses from plants and water surfaces, increased glaciers meltdown and other ice bodies. Increased drought, flood windstorms and other extreme climate phenomena, which will increase the number and intensity of disasters, reduce freshwater availability, threaten food security and human health, diminish industrial production and weaken the physical infrastructure base for socio-economic activity, resulting in reduced development. Changes in rainfall with decreased river basin run-off and less water availability for agriculture and hydropower generation which is due to changes in rainfall and river sensitivity to climate variation. Associated causes of climate change also include: rise in sea level and ocean acidification, severe droughts and floods; damage from high wind during storms; disrupted crop yield with different pests and invasive insects; heat waves and spread of disease to new areas such as cholera, dysentery, rheumatism, malaria, typhoid etc. and increased water demand and reduced water availability IPCC (2007).

Climate change has many various impacts on human habitat and livelihood conditions, and as the climate gets hotter, it even becomes more unstable. As the changes become bigger and quicker, there is the likelihood that adverse effects will keep dominating. The increasing population and industrial development has increased emission of GHGs. The use of fossil fuels, deforestation, burning and decay of biomass, etc., has led to higher atmospheric $\mathrm{CO}_{2}$ concentration, which currently is around $388 \mathrm{ppm}$ and predicted to increase to approximately $470-570 \mathrm{ppm}$ until year 2050 IPCC (2007). Table 1 below shows the sources of GHG emissions which are some of the likely causes of climate change. 


\begin{tabular}{|c|c|c|c|c|}
\hline $\begin{array}{l}\text { Green } \\
\text { House } \\
\text { Gases } \\
\end{array}$ & $\begin{array}{l}\text { Atmospheric } \\
\text { Life time }\end{array}$ & $\begin{array}{l}\text { Recent } \\
\text { Level }\end{array}$ & $\begin{array}{l}\text { Global Warming } \\
\text { Potential (in } 100 \\
\text { yrs) time zone }\end{array}$ & Main Source \\
\hline $\mathrm{CO}_{2}$ & $100 \mathrm{yrs}$ & $389 \mathrm{ppm}$ & 1 & Anthropogenic activities, fossil fuel etc. \\
\hline $\mathrm{CH}_{4}$ & $12 \mathrm{yrs}$ & $\begin{array}{l}17488^{-} \\
18709 \mathrm{ppb}\end{array}$ & 25 & Land wastes, livestock etc. \\
\hline $\mathrm{N}_{2} \mathrm{O}$ & $114 \mathrm{yrs}$ & $323 \mathrm{ppb}$ & 298 & Agriculture, industry and combustion etc. \\
\hline CFCs & $12-100 y \mathrm{ys}$ & $75-534 \mathrm{ppt}$ & $5000-10900$ & Industries, old air conditioners and refrigerators etc. \\
\hline $\mathrm{O}_{3}$ & Hours to days & $34 \mathrm{ppb}$ & n.a & Fuel combustion, organic compound evaporation etc. \\
\hline
\end{tabular}

Climate Change in Africa: Climate change scenarios for Africa, based on results from several general calculation models using data collated by the Intergovernmental Panel On Climate Change (IPCC), indicate future warming across Africa ranging from low scenario of $0.2^{\circ} \mathrm{C}$ per decade to a high scenario of more than $0.5^{\circ} \mathrm{C}$ per decade. With a more rapid warming scenario, large areas of Africa would experience rainfall that significantly exceeds natural variability in the December to February and June to August periods, with resultant adverse impacts on many sectors of the economy including agriculture, infrastructure, and health, with consequent effects on economic growth and poverty reduction. (SADF, 2010). There are different sectors which contribute to emission of GHGs and the highest proportion is from the energy sector, then followed by industry, deforestation (from tree felling, burning and slashing), intensive agricultural practices, and transport sectors. The lowest are from the residential and commercial buildings, as well as waste. All these are the sources of the overall anthropogenic activities which result to climate change. (Figure 2).

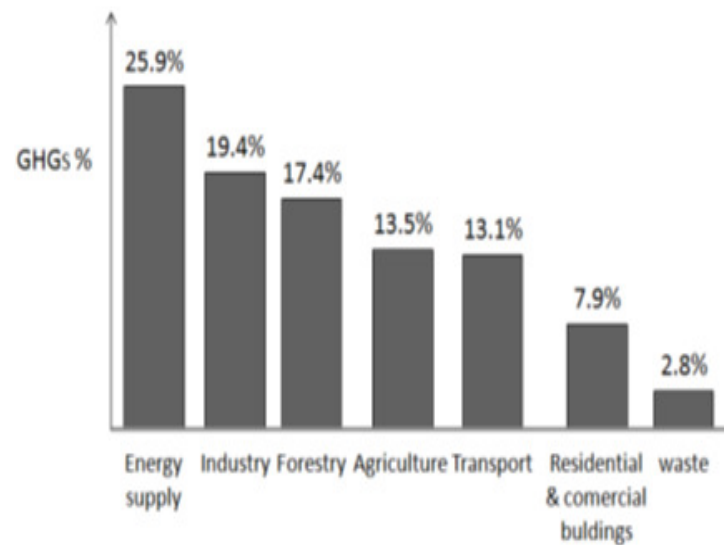

Fig 2: The sectors, which causes climate change as a result of anthropogenic activities.

Source: IPCC synthesis report (2007).

Impacts of Climate Change: The influences of climate change have become evident in the natural environment for so many years, together with other threats like habitat destruction, fragmentation, disturbances and loss in biodiversity (Lepetz et al.,
2009). For instance, the most important impact, which is the land use change in tropical forest can cause loss of biodiversity. Therefore, overexploitation of natural resources, use of hardwood timber and deforestation, will cause high loss in the amount and availability of habitats, even the extinction of species, especially the endangered.

Climate change has different effects, such as disturbances and loss of habitat, fragmentation, and increasing the incidence of photogenes. In addition, following a change in climate parameters like precipitation level, snow cover, humidity, sea level etc. There is variation in exchange of different activities in symbiotic, prediction, parasitic and mutualistic relationships (Lepetz et al., 2009). Climate change affects species indirectly by reducing the amount and availability of habitats and by eliminating essential species Morris (2010). As a result, the loss of one species can result in decrease, increase or extinction of other apparently unconnected species; however, human activities are causing secondary extinction at higher level than expected from random species losses. When species are lost from an ecosystem, it is not the only species that is lost, but the interaction and the general ecological functions, which we expect from these interactions, also will be lost (Morris, 2010).

According to FAO (2007) and Mimura, (2010) climate change impacts are classified into two broad categories;

1) Biophysical impacts: This indicates the physical impacts caused by climate change directly in the physical environment which are drought and flooding, which causes an effect on physical environment such as: effects on quality and quantity of crops, pasture, forest and livestock, change in natural resources quality and quantity of soil, land and water resources, increased weed and insect pest challenges due to climate change, shift in spatial and temporal distribution of impacts, sea level rise, change in ocean salinity, and sea temperature rise causing fish to inhabit different ranges.

2) Socio economic impacts: Subsequent to the first biophysical impacts on environment there will be 
a secondary effect on socio economic systems. For example, decline in yield and production, reduced marginal GDP from agriculture sector, fluctuation of world market price, change in geographical distribution of trade regimes, which is due to shortage of food in quality and quantity, which increases the number of people at risk and in hunger and this leads to high level of migration.

Climate change in Sub-Saharan Africa: From literature, it is known that there has been evidence of insights about the possible economic-wide consequences of harsh climate events that affect road networks in Africa, mostly consequences for food security (Cervigni et al., 2016). As illustrated in Burkina Faso by (Ndiaye et al., 2015), the variability in the price of maize is extreme in rural markets who suffer poor road network connectivity. Therefore, as climatic change intensity decreases road network connectivity, there is an increased possibility of food shortage and economic shocks to vulnerable communities (Cervigni et al., 2016). Power stations are also adversely affected when climate change impacts greatly on African countries. Besada and Sewankambo (2009) stated that in Kenya, droughts extremely affected hydropower generation between the years 1999 and 2000, and in the year 2000, the capacity went down by $25 \%$. The water level at the Akosombo dam in Ghana decreased to the minimum level of 240 feet and this led to a reduction in power generation. By scientific research, Ghana, Uganda, Ethiopia and Tanzania have experienced droughts which affected the water levels in their dams and this led to low hydropower generation (Besada and Sewankambo, 2009; Karekezi et al., 2012). Climate change impacts have the potential to exacerbate national security issues and increase the number of international conflicts. Conflicts often occur over the use of already limited natural resources, fertile ground and water. Access to consistent and dependable sources of water is significantly treasured in many African regions. However, changes in the timing and intensity of rainfall have threatened water availability and are causing conflicts over this limited resource (IPCC, 2014).

Severe drought, shoreline erosion or river and coastal flooding have displaced millions of people Abebe (2014). For instance, Abebe (2014) observed that disparaging weather conditions caused severe flooding and landslides in 2010, as a result, around 48,000 people in Uganda and 55,000 in Kenya, Namibia, Rwanda and Zambia were provisionally displaced. Henry et al., (2003) looking at the correlation between environmental factors, inter-provincial migration and using the demographic data from the population census survey, they found out that in Burkina Faso, said that, "migration is influenced by biophysical changes in the environment".

In Mali, decreasing rainfalls led to poor harvests which prompted farmers in the affected regions to migrate to the country's urban cities in search of job, especially, to the nation's capital, Bamako. This led to a population surge from 600,000 in two decades ago to approximately 2 million at present (Christian Aid, 2007). Similarly, the decline in rainfalls in Africa increased rural-urban migration within Sub-Saharan Africa (Barrios et al., 2006).

In Nigeria, particularly in the South-Eastern zone. Climate change has been a very challenging experience for the farmers in the rural area and this has led to various problems such as, low crop yield, new insects emerging, outbreak of diseases, incessant migration, river dryness, land salinity, increased temperature and intensified rainfall (Ibe et al., 2018).

Exploring further on the impact of climate change on agriculture in South-Eastern Nigeria, the level of impact in South Eastern Nigeria, particularly in Ohafia Local Government Area was assessed to be very serious. Coherently, the finding of the study in (Figure 3) reveals that majority of the sampled households, $(87.5 \%)$ strongly reputed that if crop yield keep decreasing in availability as a result of climate change impacts, it will have serious effects in its contribution to overall household livelihood and this will make agriculture loose its safety net function in time of financial shortfall or environmental crisis (Ibe, 2017).

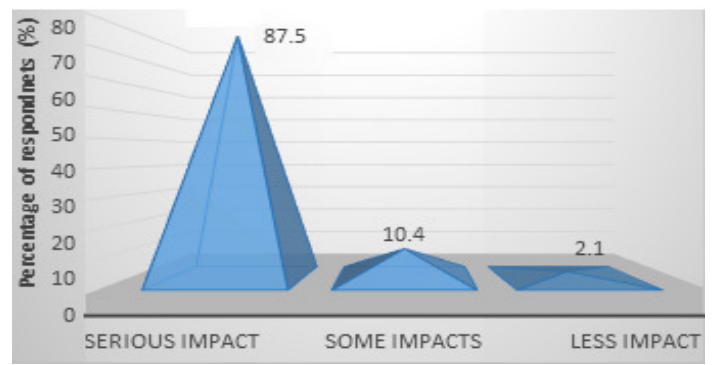

Fig 3: Level of impact of climate change on agriculture in SouthEastern Nigeria.

Source: Ibe, 2017

With an average 30 percent share of GDP and 70 to 80 percent of employment, agriculture continues to be the dominant sector in the following 19 countries below (Figure 4) with an average annual GDP growth rate of 4.5 percent or more over the period 2000 to 2006 . Additionally, because agriculture is manly rain-fed and categorized by low productivity, only 3.6 percent of arable land is irrigated, see table 2 below, these economies are constantly exposed to the risks of high 
climate variability like precipitation and extreme climatic events, especially droughts and floods, and it is not uncommon to see swings in annual GDP that exceed 30 percent. Tables 2 and 3 below shows the challenges in agriculture as a result of climate change and projected climate changes in Africa respectively.

Conclusion: This study assessed how climate change is a serious menace to agricultural productivity and ecological protection, there is a confirmation that the impacts of climate change in Africa are real. This study reveals that climate change in Africa has a very significant effect on average temperature, rainfall patterns, and extreme weather events.

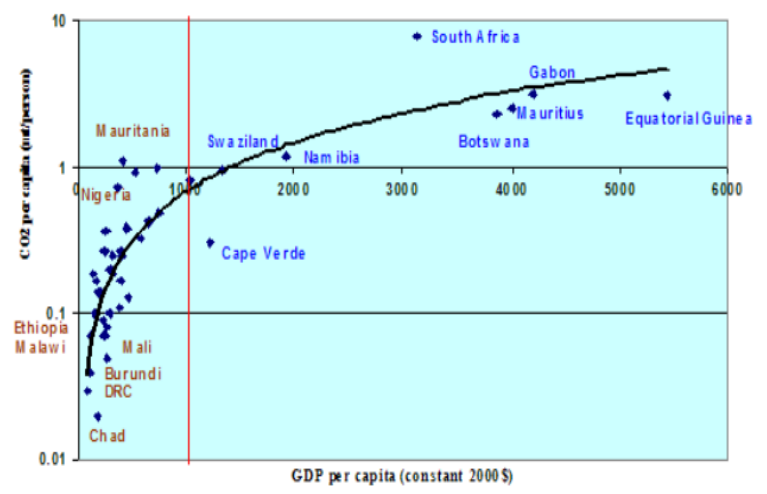

Fig 4: $\mathrm{CO}_{2}$ emissions and GDP growth 2002. Source: World Development Indicators (2002) and World Resources Institute (2002)

Table 2: Challenges in Agriculture

\begin{tabular}{lllllll}
\hline Region & $\begin{array}{l}\text { Irrigated } \\
\text { Area } \mathbf{\%} \text { of } \\
\text { cropland) }\end{array}$ & \multicolumn{3}{l}{$\begin{array}{l}\text { Fertilizer } \\
\text { Consumption } \mathbf{( k g / h a o f} \\
\text { arable land) }\end{array}$} & $\begin{array}{l}\text { Cereal yield }^{\mathbf{a}} \\
\text { (metric } \\
\text { tonnes/ha) }\end{array}$ & \\
\hline Year & $1989-1991$ & $2001-2003$ & $1989-1991$ & $2001-2003$ & $1989-1991$ & $2001-2003$ \\
SSA $^{\mathrm{b}}$ & 3.6 & 3.6 & 14.2 & 12.3 & 1.04 & 1.09 \\
\hline
\end{tabular}

Source: World Bank IEG Database 2008. a. Cereals include: wheat, rice, maize, barley, oats, rye, millet, sorghum, buckwheat, mixed grains b. Sub-Saharan Africa includes South Africa.

\begin{tabular}{ll}
\hline Change & Region \\
\hline $\begin{array}{l}\text { Average conditions } \\
\text { Temperature increase }\end{array}$ & $\begin{array}{l}\text { Entire continent (median projected increase in annual } \\
\text { average temperature: } 3 \text { to } 4^{\circ} \mathrm{C} \text { (end of century to present) } \\
\text { West coast of Africa as far south as } 15^{\circ} \mathrm{N}\end{array}$ \\
$\begin{array}{l}\text { Secrease in rainfall } \\
\text { Northern Africa }\end{array}$ & $\begin{array}{l}\text { Sahel (already high variability) } \\
\text { Guinean coast } \\
\text { Increase in rainfall }\end{array}$ \\
$\begin{array}{l}\text { Uncertain projections } \\
\text { for rainfall }\end{array}$ & $\begin{array}{l}\text { Low lying islands and coastal zones } \\
\text { Delta regions }\end{array}$ \\
Sea level rise & $\begin{array}{l}\text { Entire continent (this applies also in regions of mean } \\
\text { drying because there is a proportionally larger decrease in } \\
\text { the number of rain days) }\end{array}$ \\
$\begin{array}{l}\text { Extremes } \\
\text { Increase in intense } \\
\text { precipitation events } \\
\text { Cyclones }\end{array}$ & \multicolumn{1}{c}{ Source: IPCC, 2007}
\end{tabular}

It was also reviewed that climate has a negative effect on agricultural production and the ecological niche in Sub-Saharan Africa. Sub-Saharan Africa is indeed the most vulnerable region to climate change. To this end, policies aimed at promoting farm level adaptation strategies and mitigation of climate change with regards to human health are highly recommended. To help in climate change mitigation, there should be the establishment of more forest plantations and there should be an encouragement to continue the maintenance of the existing natural and artificial forests. Standing forests can be adopted to save biodiversity and which will help communities and natural areas cope with a changing planet.
Acknowledgement: This research is supported and funded by the UK's Department for International Development (DFID), the Climate Impacts Research Capacity and Leadership Enhancement Programme (CIRCLE) and implemented by the African Academy of Sciences and the Association of Commonwealth Universities. Sincere gratitude goes to all the reviewers for their constructive criticism and significant improvement of this paper.

\section{REFERENCES}

Abebe, MA (2014). Climate change, gender inequality and migration in East Africa. Wash. J. Envtl. L. \& Pol'y, 4, 104. 
Adetayo, AO and Owolade, EO (2012). Climate change and mitigation awareness in small farmers of Oyo State in Nigeria. Open Sci. Repository Agric. (open-access). e70081902.

Barrios, S; Albert Strobl, E; Bertinelli, L (2006). Climatic Change and Rural-Urban Migration: The Case of sub-Saharan Africa. Journal of Urban Economics, $\quad 60, \quad 357-371$. https://doi.org/10.1016/j.jue.2006.04.005.

Besada, H; Sewankambo, N (2009). CIGI Special Report: Climate Change in Africa: Adaptation, Mitigation and Governance Challenges. Retrieved from

https://www.cigionline.org/sites/default/files/climat e_change_in_africa_3.pdf.

Cervigni, R; Losos, AM; Chinowsky, P; Neumann, J L (2016). Enhancing the climate resilience of Africa's Infrastructure: the roads and bridges sector (No. 110137) (pp. 1-0). The World Bank. Retrieved from

http://documents.worldbank.org/curated/en/270671 478809724744/Enhancing-theclimate-resilienceof-Africa-s-Infrastructure-the-roads-and-bridgessector.

Christian Aid (2007). Human Tide: The Real Migration Crisis. Retrieved from https://www.christianaid.org.uk/Images/humantide.pdf.

FAO (2007). Adaptation to Climate Change in Agriculture, Forestry and Fisheries: Perspective, framework and priorities. Rome, Italy, Interdepartmental Working Group on Climate Change, FAO. 32 pp. Available at: ftp://ftp.fao.org/docrep/ fao/009/j9271e/j9271e.pdf. Accessed 8 March 2010.

Frimpong, P (2014). Burst and Bubble: The scramble for Africa's Land. Who Benefits? The Herald News Online

https://i1.wp.com/www.herald.ng/wpcontent/uploa ds/2014/03/africaland.gif

py.frimpong@yahoo.com.

Henry, S; Boyle, P; Lambin, EF (2003). Modelling inter-provincial migration in Burkina Faso, West Africa: the role of socio-demographic and environmental factors. Applied Geography, 23(2), 115-136.

https://doi.org/10.1016/j.apgeog.2002.08.001.
Ibe, GO (2017). Impact of Climate Change on Role of NTFPs to Rural dwellers in Ohafia LGA, Abia State. Unpublished work from CIRCLE post master's fellowship with Association of Commonwealth Universities, London, United Kingdom. 2017. Pp. 80.

Ibe, GO; Ezenwa, LI; Uwaga, MA; Ngwuli, CP (2018). Assessment of Challenges Faced by NonTimber Forest Products (NTFPS) Dependents'communities in a Changing Climate: A Case of Adaptation Measures in Ohafia LGA, Abia State, Nigeria. Journal of Research in Forestry, Wildlife \& Environment Vol. 10(2) June, 2018 http://www.ajol.info/index.php/jrfwe jfewr @2018 jfewr Publications E-mail: jfewr@yahoo.com ISBN: $2141-1778$. Pg. $1-10$.

Ikehi, ME (2014): Impacts of climate change on animal and crop production in Niger Delta Region of Nigeria. Res. J. Agric. Environ. Management. 3(10):528-537.

Ikehi, ME; Ifeanyi-Eze, FO; Ugwuoke, CU (2014a). Integration of climate change into the senior secondary school Agricultural Science curriculum in Nigeria. Journal of Atmospheric and Climate Sciences, 4:614-621.

ICCCSDA (2017). International Conference on Climate Change and Sustainable Development in Africa. Climate Change and Sustainable Development: strengthening Africa's adaptive capacity. Conference Book of Abstracts jointly organized by the Centre for Climate Change and Gender Studies (www.uenr.edu.gh/cccgs) and the Earth Observation Research and Innovation Centre (www.uenr.edu.gh/eoric) under the aegis of the University of Energy and Natural Resources, Sunyani, Ghana. 25 - 28 July, 2017.

IPCC (2007). Summary for Policymakers. In: Climate Change 2007: Mitigation. Contribution of Working Group III to the Fourth Assessment Report of the Intergovernmental Panel on Climate Change [B.Metz, O.R. Davidson, P.R. Bosch, R. Dave, L.A. Meyer (eds)], Cambridge University Press, Cambridge, United Kingdom and New York, NY, USA.

IPCC (2014). Summary for policymakers. In: Climate change 2014: Impacts, adaptation, and vulnerability. Part A: Global and sectoral aspects. Contribution of Working Group II to the Fifth Assessment Report of the Intergovermental Panel on Climate Change [Field CB, Barros VR, Dokken DJ, Mach KJ, 
Mastrandrea MD, Bilir TE, Chatterjee M, Ebi YL, Estrada YO, Genova RC, Girma B, Kissel ES, Levy AN, MacCracken S, Mastrandrea PR, White LL (eds)]. Cambridge University Press, Cambridge, UK and New York, USA. pp 1-32.

Karekezi, S; Kamani, J; Onguru, O; Kithyoma, W (2012). Energy Security and Adaptation to Climate Change in East Africa and the Horn of Africa: Large Scale Hydropower vs. Decentralized Renewables. Retrieved October 17, 2017, from https://ke.boell.org/2012/08/19/energy-securityandadaptation-climate-change-east-africa-andhorn-africa-large-scale.

Lepetz V; Massot, M; Schmeller, DS; Clobert, J (2009). Biodiversity monitoring: some proposals to adequately study species' responses to climate change. Biodiversity and Conservation 18, 31853203 .

Mabogunje, AL; Kröner, A; Smedley, A; McMaster, D N; Nicol, D; Middleton, J ... Steel, R W (2017). (n.d.). Africa I People, Geography, \& Facts. Retrieved October 16, 2017, from https://www.britannica.com/place/Africa.

Mimura, N (2010). Scope and roles of adaptation to climate change. In: A. Sumi, K. Fukushi, and A.Hiramatsu, eds., Adaptation and Mitigation Strategies for Climate Change. Springer Tokyo Berlin Heidelberg New York. Ch.9.

Morris, RJ (2010). Anthropogenic impacts on tropical forest biodiversity: a network structure and

Ecosystem functioning Perspective: Philosophical Transactions of the Royal Society. B 365, 37093718 .

National Geographic Society (2012). Africa: Physical Geography. Retrieved October 16, 2017, from http://www.nationalgeographic.org/encyclopedia/af rica-physical-geography/

Ndiaye, M; Elodie, M.; Le Cotty, T (2015). Maize price volatility: does market remoteness matter?
(No. WPS7202) (pp. 1-33). The World Bank. Retrieved from http://documents.worldbank.org/curated/en/132011 468184160370/Maize-price-volatility-doesmarketremoteness-matter.

SADF (2010). Seventh African Development Forum. Acting on Climate Change for Sustainable Development in Africa. Climate Change and Sustainable Development in Africa: An Overview ADF VII • 10 - 15 October 2010 - United Nations Conference Centre - Addis Ababa, Ethiopia. Pg 1 46.

United Nations (2016). The demographic profile of African countries. Addis Ababa, Ethiopia: Economic Commission for Africa. (Ed.)

UNEP (2002). United Nations Environment Programme. Invasive Alien Species. In: African Environment Outlook 2: Our Environment, Our Wealth.

WESS (2013). World Economic and Social Survey 2013. Sustainable Development Challenges. Department of Economic and Social Affairs. United Nations publication Sales No. E.13.II.C.1 Copyright @ United Nations, New York 2013. E/2013/50/Rev. 1 ST/ESA/344 ISBN 978-92-1-109167-0eISBN 978-92-1-056082-5.

World Bank (2008a). World Development Report 2008: Agriculture for Development. Washington, D.C.

World Bank (2008b). Food price crisis imperils 100 million in poor countries. News and Broadcast.Availablefromhttp://web.worldbank.org/ WBSITE/EXTERNAL/NEWS/0,,contentMDK:21 729143 pagePK:64257043 piPK:437376 theSite PK: 4607, 00.html.

World Bank PPI online database, http://ppi.worldbank.org 